(c) American Dairy Science Association, 2005.

\title{
Effects of Two Types of Emulsifying Salts on the Functionality of Nonfat Pasta Filata Cheese
}

\author{
R. Mizuno ${ }^{1,2}$ and J. A. Lucey ${ }^{2}$ \\ ${ }^{1}$ Food Research \& Development Laboratory, Morinaga Milk Industry Co., Ltd., 1-83, 5-Chome Higashihara, \\ Zama, Kanagawa 228-8583 Japan \\ ${ }^{2}$ Department of Food Science, University of Wisconsin-Madison, Madison 53706
}

\section{ABSTRACT}

Effects of 2 types of emulsifying salts (ES) on the functionality of nonfat pasta filata cheese were examined. Nonfat pasta filata cheese was made from skim milk by direct acidification. Trisodium citrate (TSC) and tetrasodium pyrophosphate (TSPP) were added to curds (at 1,3 , and 5\%, wt/wt) at the dry-salting step, together with glucono- $\delta$-lactone to maintain a constant $\mathrm{pH}$. When TSC was added, there were no significant compositional differences, although insoluble $\mathrm{Ca}$ and $\mathrm{P}$ contents significantly decreased with the addition of TSC. When TSPP was added, fat content was not significantly different, but protein content decreased with increasing concentrations of TSPP. Both insoluble Ca and $\mathrm{P}$ contents increased with the addition of $1 \%$ TSPP. The addition of ES affected textural and functional properties. With increasing concentrations of TSC, meltability increased, whereas increasing the TSPP content decreased meltability. Cheese made with $1 \%$ TSC had better stretchability compared with control cheese. However, the addition of more than 3\% TSC decreased stretchability. Addition of TSPP caused a considerable decrease in stretchabilty. Scanning electron microscopy revealed that the size and number of serum pockets decreased and protein appeared more hydrated with the addition of both ES. These results suggested that TSC and TSPP influenced the functionality of nonfat pasta filata cheese differently; that is, the effects of TSC were probably caused by a decrease in the number of colloidal calcium phosphate cross-links and an increase in electrostatic repulsion, whereas the effects of TSPP may have been related to the formation of new TSPP-induced casein-casein interactions.

(Key words: pasta filata, nonfat cheese, emulsifying salt, functionality)

Abbreviation key: CCP = colloidal Ca phosphate, $\mathbf{E S}=$ emulsifying salts, $\mathbf{G}^{\prime}=$ storage modulus, $\mathbf{L T}=$

Received March 25, 2005.

Accepted June 26, 2005.

Corresponding author: John A. Lucey; e-mail: jalucey@wisc.edu. loss tangent, $\mathbf{L} \mathbf{T}_{\max }=$ maximum loss tangent, $\mathbf{T S C}=$ trisodium citrate, $\mathbf{T S P P}=$ tetrasodium pyrophosphate.

\section{INTRODUCTION}

Pasta filata-type cheese, especially Mozzarella cheese, is the most popular cheese variety in the United States with over 1.25 million tonnes produced in 2002 (IDFA, 2004). Low moisture, part-skim Mozzarella is commonly used as an ingredient in pizza because of its excellent functionalities (e.g., meltability, stretchability, and shredability). Some people who are conscious of their health avoid consuming cheese products, because of the relatively high fat content. There has been extensive research to try to develop reduced- and nonfat cheese products of acceptable quality (e.g., Merrill et al., 1994; Rudan and Barbano, 1998; Rudan et al., 1999; Sheehan and Guinee, 2004). However, reducing or removing fat can adversely affect cheese quality. Various defects that are frequently encountered include atypical color, poor meltability, excessive chewiness, dry and dull melted surface, and excessive scorching or burning.

Research on improving these defects has been carried out. Homogenization of milk for reduced-fat Mozzarella cheese resulted in a whiter cheese than that made from unhomogenized reduced-fat milk (Rudan et al., 1998). Increasing the moisture content or decreasing the protein content is also helpful for improving meltability and reducing the firm texture (Tunick et al., 1991; Merrill et al., 1994). Metzger et al. (2000, 2001a,b) preacidified cheese milk and reduced the total Ca content, and observed a softer texture and an improved melt in lowfat Mozzarella cheese. Another option is to add an ingredient that could modify the physicochemical characteristics of reduced- and nonfat cheese, such as for promoting casein solubilization, as this would be useful for improving cheese functionality. Emulsifying salts (ES) have the ability to solubilize and hydrate protein during processed cheese manufacture (Berger et al., 1998; Fox et al., 2000). There have been several studies where ES was added to pasta filata cheese to shorten the aging period required to achieve acceptable functionality, to provide good baking performance, or to remove the hot 
water stretching process (Barz and Cremer, 1993, 1996; Barz et al., 1999; Rizvi et al., 1999; Dahlstrom et al., 2001). Emulsifying salts are not listed as optional ingredients in most current standards of identity for various cheese varieties (including Mozzarella), so we will use the term "pasta filata-type cheese". Despite the use of ES in natural cheese being a regulatory or labeling "gray area" there is no doubt from the list of industrial patents cited above that these types of cheeses are currently being manufactured. In our previous research (Mizuno and Lucey, 2005), the effects of 4 types of ES, which are commonly used in processed cheese manufacture, on casein micelles were examined. This research indicated that trisodium citrate (TSC) and tetrasodium pyrophosphate (TSPP) influenced casein micelles by very different mechanisms. The objective of this study was to determine the impact of the addition of TSC and TSPP on the texture and functionality of nonfat pasta filata cheese.

\section{MATERIALS AND METHODS}

\section{Cheese Manufacture}

Nineteen kilograms of pasteurized $\left(76^{\circ} \mathrm{C}\right.$ for $\left.18 \mathrm{~s}\right)$ skim milk, which was obtained from University of Wisconsin-Madison Dairy Plant (Madison, WI), was transferred to a custom-made (Labtronix Inc., Monroe, OR) 20-L mini-scale cheese vat with automatic stirring controls, and acidified directly to $\mathrm{pH} 5.8$ with lactic acid $(27 \%, \mathrm{wt} / \mathrm{wt})$ at $4^{\circ} \mathrm{C}$. After $\mathrm{pH}$ became approximately constant $(\sim 30 \mathrm{~min})$, cheese milk was heated to $36^{\circ} \mathrm{C}$, and $0.5 \mathrm{~g}$ of chymosin (Chymostar Double Strength; Rhodia, Cranbury, NJ) was added. Before addition, the chymosin was diluted with $\sim 10 \mathrm{~mL}$ of milli-Q water. After coagulation for $\sim 15 \mathrm{~min}$, the coagulum was cut into $\sim 10$-mm cubes. After cutting, the curd-whey mixture was allowed to heal for $5 \mathrm{~min}$, and then stirred for 30 min to prevent curds from fusing together. The curdwhey mixture was heated to $42^{\circ} \mathrm{C}$ at a rate of $0.5^{\circ} \mathrm{C} /$ min. Each vat was cooked at $42^{\circ} \mathrm{C}$ with stirring for 30 min, and then the whey was drained. The curds were milled to a size of $\sim 2 \mathrm{~cm}$. Trisodium citrate dihydrate (Sigma-Aldrich, St. Louis, MO) or TSPP (Astaris, St. Louis, $\mathrm{MO}$ ), glucono- $\delta$-lactone, and $\mathrm{NaCl}$ were added to milled curds. Glucono- $\delta$-lactone was added to keep the $\mathrm{pH}$ constant as the addition of ES altered curd $\mathrm{pH}$. The amount of glucono- $\delta$-lactone added was 0.35 and 1.00 times as much as that of TSC and TSPP, respectively. Sodium chloride was added at a level of $1 \%(\mathrm{wt} / \mathrm{wt})$ of curd. After mellowing for $20 \mathrm{~min}, 5 \mathrm{~L}$ of hot water $\left(\sim 75^{\circ} \mathrm{C}\right)$ was added. After soaking for $1 \mathrm{~min}$, hot water was drained, and curd was stretched for 1 min by hand. Then, hot water was added again. This procedure was repeated until the temperature of the curd reached $\sim 58^{\circ} \mathrm{C}$ (usually 3 times). String cheese was made by stretching some of the curd in one direction so that cheese fibers had a uniform orientation. This treatment was performed for each trial. The hot curd was molded into a 700-mL rectangular plastic container (except for string cheese-type samples) and immersed in ice water for $120 \mathrm{~min}$. The cheese was removed from the mold after $30 \mathrm{~min}$, and curd was vacuum-wrapped $60 \mathrm{~min}$ after the start of cooling. After stretching, the stringtype cheese was immersed into ice water for $30 \mathrm{~min}$ and cheese was then wrapped with plastic wrap. Both types of cheeses were stored at $4^{\circ} \mathrm{C}$. The functionalities of cheeses were measured $2 \mathrm{~d}$ after manufacture except stretchability, which was measured $1 \mathrm{~d}$ after manufacture. Cheese making was performed in triplicate. All cheese samples for compositional analysis and functional tests were prepared as follows. The outside cheese surface was cut away to a depth of $\sim 1 \mathrm{~cm}$. Sampling was performed at 3 different places in the interior of the cheese block.

\section{Compositional Analysis}

Cheese samples were analyzed for moisture (IDF, 1982a), fat (Marshall, 1992), protein (total percentage of $\mathrm{N} \times 6.38$ ) by Kjeldahl (IDF, 1986), and $\mathrm{pH}$ by insertion of a pH probe ( $\mathrm{pH}$ meter 420A; Orion Research, Beverly, MA) into a cheese block. Cheese juice samples were analyzed for total solids (IDF, 1982b) and protein (IDF, 1986). Calcium and $P$ in cheese and cheese juice were measured by inductively coupled argon plasma emission spectroscopy (Vista-MPX Simultaneous ICP-OES; Varian, Palo Alto, CA). Wavelengths used for measurements were 317.9 and $214.9 \mathrm{~nm}$ for $\mathrm{Ca}$ and $\mathrm{P}$, respectively (Park, 2000). Insoluble Ca and insoluble P contents in cheese were calculated from the analysis of cheese and cheese juice, based on the methods of Morris et al. (1988), using the following type of equations:

$$
\begin{gathered}
\text { Insoluble Ca }(\mathrm{mg} / \mathrm{g} \text { protein })=\left(\frac{m_{C a}}{H}-\frac{m_{C a}^{\prime}}{H^{\prime}}\right) \times \frac{H}{P r} \\
\text { Insoluble } P(m g / g \text { protein })=\left(\frac{m_{P}}{H}-\frac{m_{P}^{\prime}}{H^{\prime}}\right) \times \frac{H}{P r}
\end{gathered}
$$

where $m_{C a}$ and $m_{C a}^{\prime}$ are the concentrations (mg/100 g) of $\mathrm{Ca}$ in cheese and juice, respectively, $H$ and $H^{\prime}$ are the percentage of moisture in cheese and juice, respectively, $P r$ is the percentage of protein in cheese, and $m_{P}$ and $m_{P}^{\prime}$ are the concentrations $(\mathrm{mg} / 100 \mathrm{~g})$ of $\mathrm{P}$ in cheese and juice, respectively. 


\section{Cheese Juice Extraction}

Cheese juice was extracted $2 \mathrm{~d}$ after manufacture as described by Hassan et al. (2004). Eight hundred grams of grated cheese was mixed with $1100 \mathrm{~g}$ of washed sea sand (Fisher Scientific, Pittsburgh, PA). The mixture was placed into a perforated stainless steel hoop, which was lined with cheesecloth (Pyrex Heavy Duty Cheesecloth, Robinson Knife Company, Buffalo, NY). The hoop, which was filled with the cheese and sand mixture, was placed on the press plate and pressed using a hydraulic press (Fred S. Carver, Summit, NJ) at $25^{\circ} \mathrm{C}$. Pressure was increased gradually over $5 \mathrm{~h}$ up to 14 $\mathrm{MPa}$. Juice was collected until the flow had virtually stopped. Juice was centrifuged at $1600 \times g$ at $4^{\circ} \mathrm{C}$ for 10 min (CR3i Centrifuge, Jouan, Winchester, VA) to remove small curd particles.

\section{Textural Profile Analysis}

Two days after cheese making, a cylindrical sample (16 $\mathrm{mm}$ diameter and $18 \mathrm{~mm}$ height) of cheese was taken from each cheese, placed in a plastic bag, and held at $\sim 4^{\circ} \mathrm{C}$ overnight. Cheese was allowed to warm to $10^{\circ} \mathrm{C}$ by storing at $10^{\circ} \mathrm{C}$ for $\sim 2 \mathrm{~h}$ before measurements, and then compressed twice to $75 \%$ of original height using a Texture Analyzer TA-XT2 (Stable Micro Systems, Godalming, Surrey, UK). Hardness, cohesiveness, adhesiveness, and chewiness were calculated as described by Bourne (1968). Measurements were performed in triplicate.

\section{Small-Amplitude Oscillatory Shear}

Changes in viscoelastic properties of cheese on heating from 5 to $85^{\circ} \mathrm{C}$ were measured using a controlledstress rheometer (Universal Dynamic Spectrometer, Paar Physica UDS 200, Physica Messtechnik GmbH, Stuttgart, Germany). A serrated plate measuring system (MP31P, $50 \mathrm{~mm}$ diameter) with peltier heating was used to test cheese $2 \mathrm{~d}$ after manufacture. A cylindrical sample (50 $\mathrm{mm}$ diameter and $3.5 \mathrm{~mm}$ height) was taken from each cheese, placed in a plastic bag, and held at $\sim 4^{\circ} \mathrm{C}$ overnight. Cheese was tested at an applied strain of $0.2 \%$ and a frequency of $0.1 \mathrm{~Hz}$. Storage modulus $\left(\mathbf{G}^{\prime}\right)$ and loss tangent $(\mathbf{L T})$ were calculated during heating. The storage modulus $G^{\prime}$ is a measure of the energy stored and released per oscillation cycle, which can be used as the index of stiffness or elastic character (and when it decreases, it indicates softening of the cheese) (Lucey et al., 2003). Loss tangent indicates the ratio of viscous to elastic properties and is related to the relaxation of bonds in the matrix (Lucey, 2002), which can be used as an index of meltability or flowability of cheese (Lucey et al., 2003). Measurements were performed in triplicate.

\section{Meltability}

The UW Melt Profiler, designed by Muthukumarappan et al. (1999), was used to determine melting properties of cheese $2 \mathrm{~d}$ after manufacture. A cylindrical sample (30 $\mathrm{mm}$ diameter and $7 \mathrm{~mm}$ height) was taken from each cheese, placed in a plastic bag, and held at $\sim 4^{\circ} \mathrm{C}$ overnight. The sample was placed between 2 aluminum plates in an oven at $72^{\circ} \mathrm{C}$ and a wire thermocouple was inserted into the sample. During cheese melting, the distance between plates (i.e., cheese height) decreased. Meltability was determined by comparing the height of melted cheese to the initial height, i.e., melt profiles. Measurements were performed in triplicate.

\section{Stretchability}

Stretchability of cheese samples was empirically measured by the fork test (Gunasekaran and Ak, 2002). One day after cheese making, $75 \mathrm{~g}$ of shredded cheese was placed on a quarter of pizza crust $(30.5 \mathrm{~cm}$ diameter, Arrezzio Originale; Sysco, Houston, TX) with $8 \mathrm{~g}$ of tomato paste that was spread on the crust. Two types of pizza ovens were used to bake pizzas. One pizza was baked in a conventional (i.e., not fan-assisted) oven (Bakers Pride, New Rochelle, NY) at $232^{\circ} \mathrm{C}$ for $12 \mathrm{~min}$, and the other pizza was baked in an Impinger (forcedair) oven (Lincoln Foodservice Products Inc., Fort Wayne, IN) at $260^{\circ} \mathrm{C}$ for $5 \mathrm{~min}$. The fork test was performed 1 min after the pizza was taken out of the oven. Melted cheese was lifted up using a fork until the strands broke and the height when strands broke was recorded as the strand length. Stretchability was calculated as an average of the strand length between the 2 types of ovens. Measurements were performed in triplicate.

\section{Scanning Electron Microscopy}

Scanning electron microscopy was used to observe changes in microstructure of nonfat pasta filata cheese and string-type cheese, as described by Kuo and Gunasekaran (2003). Two days after cheese making, cheese was cut into a cube sample $(1 \times 1 \times 10 \mathrm{~mm}$ for nonfat pasta filata cheese or $1 \times 5 \times 10 \mathrm{~mm}$ for string-type cheese), and fixed in $2.5 \%$ glutaraldehyde in a $0.05 \mathrm{M}$ sodium phosphate buffer $(\mathrm{pH} 6)$ for $48 \mathrm{~h}$ at $7^{\circ} \mathrm{C}$. Fixed samples were dehydrated in a graded ethanol series $(50,70,80,95,100,100$, and 100\%) for $15 \mathrm{~min}$, defatted in chloroform, 3 changes in chloroform for $15 \mathrm{~min}$, and dehydrated again in 100\% ethanol with 3 changes for 15 
Table 1. Composition of nonfat pasta filata cheese and juice made using different concentrations of added trisodium citrate (TSC).

\begin{tabular}{|c|c|c|c|c|c|}
\hline & \multicolumn{4}{|c|}{ Treatment } & \multirow[b]{2}{*}{ SEM } \\
\hline & Control & $1 \% \mathrm{TSC}$ & $3 \%$ TSC & $5 \% \mathrm{TSC}$ & \\
\hline \multicolumn{6}{|l|}{ Cheese } \\
\hline $\mathrm{pH}$ at $1 \mathrm{~d}$ & $5.99^{\mathrm{a}}$ & $6.08^{\mathrm{a}}$ & $6.05^{\mathrm{a}}$ & $6.03^{\mathrm{a}}$ & 0.01 \\
\hline Fat, \% wt/wt & $1.4^{\mathrm{a}}$ & $1.7^{\mathrm{a}}$ & $1.4^{\mathrm{a}}$ & $1.2^{\mathrm{a}}$ & 0.08 \\
\hline Moisture, \% wt/wt & $57.1^{\mathrm{a}}$ & $57.0^{\mathrm{a}}$ & $56.6^{\mathrm{a}}$ & $56.1^{\mathrm{a}}$ & 0.20 \\
\hline Protein, \% wt/wt & $36.2^{\mathrm{a}}$ & $35.9^{\mathrm{a}}$ & $36.3^{\mathrm{a}}$ & $36.7^{\mathrm{a}}$ & 0.12 \\
\hline $\mathrm{Ca}, \mathrm{mg} / 100 \mathrm{~g}$ of cheese & $608^{\mathrm{a}}$ & $611^{\mathrm{a}}$ & $620^{\mathrm{a}}$ & $580^{\mathrm{b}}$ & 5.86 \\
\hline $\mathrm{P}, \mathrm{mg} / 100 \mathrm{~g}$ of cheese & $489^{\mathrm{bc}}$ & $470^{\mathrm{c}}$ & $507^{\mathrm{a}}$ & $499^{\mathrm{ab}}$ & 4.83 \\
\hline \multicolumn{6}{|l|}{ Juice } \\
\hline Moisture, \% wt/wt & $92.3^{\mathrm{a}}$ & $91.7^{\mathrm{b}}$ & $90.4^{\mathrm{c}}$ & $\mathrm{ND}^{1}$ & 0.30 \\
\hline Protein, \% wt/wt & $1.22^{\mathrm{b}}$ & $2.10^{\mathrm{a}}$ & $2.35^{\mathrm{a}}$ & ND & 0.19 \\
\hline $\mathrm{Ca}, \mathrm{mg} / 100 \mathrm{~g}$ of juice & $108^{b}$ & $132^{\mathrm{a}}$ & $139^{\mathrm{a}}$ & ND & 6.07 \\
\hline $\mathrm{P}, \mathrm{mg} / 100 \mathrm{~g}$ of juice & $81^{b}$ & $92^{\mathrm{b}}$ & $123^{\mathrm{a}}$ & ND & 4.85 \\
\hline Insoluble $\mathrm{Ca}, \mathrm{mg} / \mathrm{g}$ of protein & $15.0^{\mathrm{a}}$ & $14.7^{\mathrm{b}}$ & $14.7^{\mathrm{b}}$ & ND & 0.06 \\
\hline Insoluble $\mathrm{P}, \mathrm{mg} / \mathrm{g}$ of protein & $12.2^{\mathrm{a}}$ & $11.5^{\mathrm{b}}$ & $11.7^{\mathrm{b}}$ & ND & 0.05 \\
\hline
\end{tabular}

min. Samples were rapidly frozen using liquid nitrogen and fractured. Samples were thawed in $100 \%$ ethanol and critical-point dried with liquid carbon dioxide. Dried samples were mounted on an aluminum scanning electron microscopy stub and coated with gold. The microstructure of samples was observed using a Hitachi S-570 LaB6 scanning electron microscope (Hitachi, Tokyo, Japan) at an accelerating voltage of $10 \mathrm{kV}$. Numerous fields were viewed and representative images taken.

\section{Statistical Analysis}

A randomized complete block design, which incorporated the 4 treatments (control and 1, 3, and 5\% ES levels) and 3 blocks, was used to analyze the response variables relating to composition and functional properties of the cheeses. An ANOVA was carried out using the SAS program (SAS Institute, 1999). The level of significance was determined at $P<0.05$.

\section{RESULTS}

\section{Composition}

The composition of cheese in the TSC trials is summarized in Table 1 . The $\mathrm{pH}$ of all cheeses were adjusted by adding glucono- $\delta$-lactone, to be the same as control cheese. The $\mathrm{pH}$ of control cheese was $\sim 6.0$ despite the adjustment of $\mathrm{pH}$ of cheese milk to 5.8 (Table 1). This small increase in $\mathrm{pH}$ value was probably due to the loss of lactic acid in the stretch water and to slow solubilization of colloidal calcium phosphate (CCP). There were no significant differences in fat, moisture, and protein contents among the cheeses. Several cheese samples were analyzed for $\mathrm{NaCl}$ content, and the salt-in-moisture content of the cheeses was $\sim 1 \%$ (results not shown). The amount of total $\mathrm{Ca}$ in the cheeses made with added TSC was not significantly different from that in control cheese except for cheese with 5\% TSC added, which was lower than the control and other cheeses with added TSC. The amount of total $\mathrm{P}$ in cheese did not show any obvious trend, with an increase in the amount of added TSC. Cheese juice was expressed from cheese with 0,1 , and $3 \%$ addition of TSC. No cheese juice could be expressed from cheese with the addition of $5 \%$ TSC, probably due to an increase in water-holding capacity of protein and a decrease in free water. Protein content of juice increased as the amount of added TSC increased. This was due to the solubilization of protein by TSC. The concentration of $\mathrm{Ca}$ and $\mathrm{P}$ in juice also increased with increasing concentration of added TSC. The insoluble Ca content of control cheese was $15.0 \mathrm{mg} /$ $\mathrm{g}$ of protein. As shown in Table 1, insoluble Ca content per gram of protein significantly decreased with an increase in the amount of added TSC. Insoluble $\mathrm{P}$ also decreased significantly in cheese with 1 or $3 \%$ TSC added.

The compositions of cheeses in the TSPP trials are summarized in Table 2. Fat content was not significantly different in cheese samples. Moisture content was not significantly different in control, or cheese with 1 and $3 \%$ TSPP added. However, cheese with 5\% TSPP added had a relatively low moisture content. This could be due to excessive dehydration of curd during salting due to the very high amount of TSPP added. Protein content of cheese decreased as the amount of added TSPP increased, possibly due to increased protein losses in the stretching water, although the protein 
Table 2. Composition of nonfat pasta filata cheese and juice made using different concentrations of added tetrasodium pyrophosphate (TSPP).

\begin{tabular}{|c|c|c|c|c|c|}
\hline & \multicolumn{4}{|c|}{ Treatment } & \multirow[b]{2}{*}{ SEM } \\
\hline & Control & $1 \%$ TSPP & $3 \%$ TSPP & $5 \%$ TSPP & \\
\hline \multicolumn{6}{|l|}{ Cheese } \\
\hline $\mathrm{pH}$ at $1 \mathrm{~d}$ & $5.99^{\mathrm{a}}$ & $6.01^{\mathrm{a}}$ & $5.93^{\mathrm{a}}$ & $5.98^{\mathrm{a}}$ & 0.01 \\
\hline Fat, \% wt/wt & $1.4^{\mathrm{a}}$ & $1.5^{\mathrm{a}}$ & $1.5^{\mathrm{a}}$ & $1.4^{\mathrm{a}}$ & 0.08 \\
\hline Moisture, \% wt/wt & $57.1^{\mathrm{ab}}$ & $58.0^{\mathrm{a}}$ & $57.7^{\mathrm{a}}$ & $56.4^{\mathrm{b}}$ & 0.19 \\
\hline Protein, \% wt/wt & $36.2^{\mathrm{a}}$ & $34.8^{\mathrm{b}}$ & $32.8^{\mathrm{c}}$ & $32.8^{\mathrm{c}}$ & 0.42 \\
\hline $\mathrm{Ca}, \mathrm{mg} / 100 \mathrm{~g}$ of cheese & $608^{\mathrm{a}}$ & $620^{\mathrm{a}}$ & $636^{\mathrm{a}}$ & $614^{\mathrm{a}}$ & 6.78 \\
\hline $\mathrm{P}, \mathrm{mg} / 100 \mathrm{~g}$ of cheese & $489^{\mathrm{c}}$ & $598^{\mathrm{b}}$ & $773^{\mathrm{a}}$ & $775^{\mathrm{a}}$ & 31.1 \\
\hline \multicolumn{6}{|l|}{ Juice } \\
\hline Moisture, $\% \mathrm{wt} / \mathrm{wt}$ & $92.3^{\mathrm{a}}$ & $91.2^{\mathrm{b}}$ & $\mathrm{ND}^{1}$ & ND & 0.25 \\
\hline Protein, \% wt/wt & $1.22^{\mathrm{b}}$ & $2.22^{\mathrm{a}}$ & ND & ND & 0.21 \\
\hline $\mathrm{Ca}, \mathrm{mg} / 100 \mathrm{~g}$ of juice & $108^{\mathrm{a}}$ & $105^{\mathrm{a}}$ & ND & ND & 0.70 \\
\hline $\mathrm{P}, \mathrm{mg} / 100 \mathrm{~g}$ of juice & $81^{\mathrm{b}}$ & $152^{\mathrm{a}}$ & ND & ND & 14.9 \\
\hline Insoluble $\mathrm{Ca}, \mathrm{mg} / \mathrm{g}$ of protein & $15.0^{\mathrm{b}}$ & $15.9^{\mathrm{a}}$ & ND & ND & 0.11 \\
\hline Insoluble $\mathrm{P}, \mathrm{mg} / \mathrm{g}$ of protein & $12.2^{\mathrm{b}}$ & $14.4^{\mathrm{a}}$ & ND & ND & 0.16 \\
\hline
\end{tabular}

content in stretching water was not measured in this study. Total Ca content in cheese was not significantly affected by the addition of TSPP. Total P content of cheese increased with the addition of TSPP and the P content for cheese with 5\% TSPP added increased by $58 \%$ compared with control cheese. This was due to $\mathrm{P}$ added by this type of ES. Cheese juice could only be expressed from the cheese with 1\% TSPP added. Protein content in juice significantly increased with the addition of $1 \%$ TSPP, probably due to some solubilization of casein. Calcium content in juice did not change when $1 \%$ TSPP was added to curd, although the $\mathrm{P}$ content of juice significantly increased. Both insoluble $\mathrm{Ca}$ and $\mathrm{P}$ contents increased significantly with the addition of $1 \%$ TSPP to cheese.

\section{Texture Profile Analysis}

The texture profile analysis parameters of cheese made with various concentrations of added TSC are shown in Table 3. The hardness values of all cheeses made with added TSC were lower than that of control cheese. When the amount of added TSC increased, hardness tended to decrease, except for the cheese with $5 \%$ TSC added. Cohesiveness decreased, adhesiveness greatly increased, and chewiness decreased in cheese with increasing level of added TSC. When TSPP was added to cheese (Table 4), the trends in the texture profile analysis parameters were similar, although the extent of these changes was larger compared with those when TSC was added to cheese.

\section{Small-Amplitude Oscillatory Shear}

Changes in $\mathrm{G}^{\prime}$ as a function of temperature for cheese with TSC and TSPP added are shown in Figure 1. Increasing temperature resulted in a decrease in $G^{\prime}$ for all cheeses. For cheese with added TSC, $\mathrm{G}^{\prime}$ values at high temperature $\left(>60^{\circ} \mathrm{C}\right)$ became lower with increasing concentrations of added TSC, although the degree of this reduction was small (Figure 1a), whereas $\mathrm{G}^{\prime}$ values at low temperature $\left(<20^{\circ} \mathrm{C}\right)$ exhibited the opposite trend-with increasing level of added TSC, the $\mathrm{G}^{\prime}$ values slightly increased.

Cheese with added TSPP had larger changes in $\mathrm{G}^{\prime}$ values when heated (Figure 1b). The $G^{\prime}$ values of cheese

Table 3. Texture profile analysis parameters of nonfat pasta filata cheese made with different concentrations of added trisodium citrate (TSC).

\begin{tabular}{lclccc}
\hline & \multicolumn{4}{c}{ Treatment } & \\
\cline { 2 - 5 } & Control & $1 \%$ TSC & $3 \%$ TSC & $5 \%$ TSC & SEM \\
\hline Hardness, $\mathrm{N}$ & $10.13^{\mathrm{a}}$ & $9.02^{\mathrm{b}}$ & $8.55^{\mathrm{b}}$ & $9.12^{\mathrm{ab}}$ & 0.21 \\
Cohesiveness & $0.81^{\mathrm{a}}$ & $0.81^{\mathrm{a}}$ & $0.78^{\mathrm{b}}$ & $0.77^{\mathrm{b}}$ & 0.004 \\
Adhesiveness, $\times 10^{5} \mathrm{~N} \cdot \mathrm{m}$ & $3.35^{\mathrm{c}}$ & $5.20^{\mathrm{bc}}$ & $13.53^{\mathrm{b}}$ & $31.04^{\mathrm{a}}$ & 2.12 \\
Chewiness, $\times 10^{2} \mathrm{~N} \cdot \mathrm{m}$ & $3.30^{\mathrm{a}}$ & $3.09^{\mathrm{ab}}$ & $2.54^{\mathrm{c}}$ & $2.76^{\mathrm{bc}}$ & 0.08 \\
\hline
\end{tabular}

${ }^{\mathrm{a}, \mathrm{b}, \mathrm{c}}$ Superscripts with different letters within the same row are significantly different $(P<0.05)$. 
Table 4. Texture profile analysis parameters of nonfat pasta filata cheese made with different concentrations of added tetrasodium pyrophosphate (TSPP).

\begin{tabular}{lclccc}
\hline & \multicolumn{3}{c}{ Treatment } & \\
\cline { 2 - 5 } & Control & $1 \%$ TSPP & $3 \%$ TSPP & $5 \%$ TSPP & SEM \\
\hline Hardness, $\mathrm{N}$ & $10.13^{\mathrm{a}}$ & $8.92^{\mathrm{b}}$ & $8.68^{\mathrm{b}}$ & $8.48^{\mathrm{b}}$ & 0.19 \\
Cohesiveness & $0.81^{\mathrm{a}}$ & $0.77^{\mathrm{b}}$ & $0.73^{\mathrm{c}}$ & $0.74^{\mathrm{c}}$ & 0.006 \\
Adhesiveness, $\times 10^{5} \mathrm{~N} \cdot \mathrm{m}$ & $3.35^{\mathrm{c}}$ & $3.61^{\mathrm{c}}$ & $24.43^{\mathrm{b}}$ & $30.90^{\mathrm{a}}$ & 2.44 \\
Chewiness, $\times 10^{2} \mathrm{~N} \cdot \mathrm{m}$ & $3.30^{\mathrm{a}}$ & $2.72^{\mathrm{b}}$ & $2.85^{\mathrm{b}}$ & $2.37^{\mathrm{c}}$ & 0.09 \\
\hline
\end{tabular}

${ }^{\mathrm{a}, \mathrm{b}, \mathrm{c}}$ Superscripts with different letters within the same row are significantly different $(P<0.05)$.

with $1 \%$ TSPP added were significantly lower than that of control until cheese was heated to $\geq 75^{\circ} \mathrm{C}$. In cheeses with high levels of added TSPP (i.e., 3 and 5\%), the $\mathrm{G}^{\prime}$ values at $\geq 60^{\circ} \mathrm{C}$ did not decrease further and stayed constant even up to $85^{\circ} \mathrm{C}$.

Changes in LT for cheeses made with added TSC and TSPP are shown in Figure 2. At low temperatures $\left(<30^{\circ} \mathrm{C}\right)$, LT values for cheeses made with added TSC hardly changed (Figure 2a). With increasing temperature $\left(>40^{\circ} \mathrm{C}\right)$, LT values gradually increased, depending on the concentration of added TSC. Values of LT reached a maximum $\left(\mathrm{LT}_{\max }\right)$ around $70^{\circ} \mathrm{C}$ and decreased at higher temperature. Comparing the $\mathrm{LT}_{\max }$ value between cheeses, with higher concentrations of added TSC, a higher $\mathrm{LT}_{\max }$ value was observed ( $\mathrm{LT}_{\max }$ values for control and cheese with 5\% TSC added were $\sim 2.7$ and 3.5, respectively; Figure 2a).

When cheeses with added TSPP were heated, the $\mathrm{LT}_{\max }$ value dramatically decreased with increasing TSPP concentration (Figure $2 \mathrm{~b}$ ). The $\mathrm{LT}_{\max }$ value for cheese with 5\% TSPP added decreased to 0.8 , which was only $\sim 30 \%$ that for control cheese. Moreover, the temperature at which $\mathrm{LT}_{\max }$ occurred was lower $\left(\sim 50^{\circ} \mathrm{C}\right)$.

\section{Meltability and Stretchability}

The melt profiles of cheese made with various concentrations of TSC are shown in Figure 3a. The height of cheese decreased with increasing temperature and the height of control cheese decreased to $32 \%$ compared with its initial height after 15 min of heating in a $72^{\circ} \mathrm{C}$ oven (when the cheese temperature was $\sim 64^{\circ} \mathrm{C}$; Figure $3 a)$. With increasing concentrations of TSC, the extent of the decrease in cheese height became larger (meltability increased); for example, for cheese made with $5 \%$ TSC, the height decreased to $19 \%$ of its initial height after heating.

When cheese made with added TSPP was heated, the melt profiles exhibited the opposite trend to cheeses made with added TSC (Figure 3b). Meltability of cheese with added TSPP decreased with increasing concentrations of ES. At the highest TSPP concentration (5\%), very limited melt occurred; that is, cheese height only decreased to $68 \%$ of initial height after heating (Figure $3 b$ ).

After baking in the oven, control cheese had a dried surface, limited melt, and poor shred fusion. When TSC was added to cheese, shreds of cheese had less identity after baking. In cheese made with 5\% TSC, cheese became very fluid and flowed off the pizza crust. When cheese made with $1 \%$ TSC was lifted up by fork, the length of stretch was greater than that of control cheese (Figure 4). However, when more TSC was added, stretchability slightly decreased, although the length was still greater than that of control.

Cheese made with TSPP also had a dried surface but it had limited melt and individual shreds were visible after baking. The addition of $1 \%$ TSPP to cheese did not affect the length of stretch (Figure 4); however, the addition of 3\% TSPP greatly decreased stretchability, which was similar to cheese with 5\% TSPP (Figure 4).

\section{Microstructure}

The addition of ES to nonfat pasta filata cheese greatly affected the microstructure (Figure 5). The control cheese had several well-distributed pores, most of which were presumably serum pockets and not fat globules because it was a nonfat cheese (Figure 5a). Cheese made with $1 \%$ TSC still had some serum pockets, but they were smaller and fewer compared with control cheese, and the cheese surface appeared rougher than the control (Figure 5b). When 5\% TSC was added to cheese curd, serum pockets became very small and less numerous (Figure 5c). In cheese with $1 \%$ TSPP, serum pockets were smaller than those of control cheese, and the microstructure appeared somewhat similar to cheese made with $1 \%$ TSC added (Figure $5 \mathrm{~d}$ ). With the addition of 5\% TSPP, serum pockets almost disappeared and the protein structure became more homogeneous and had a smooth surface (Figure 5e).

The micrographs of string-type cheese samples made from the ES-treated cheeses are shown in Figure 6. The control cheese had a fine and clearly fibrous structure 


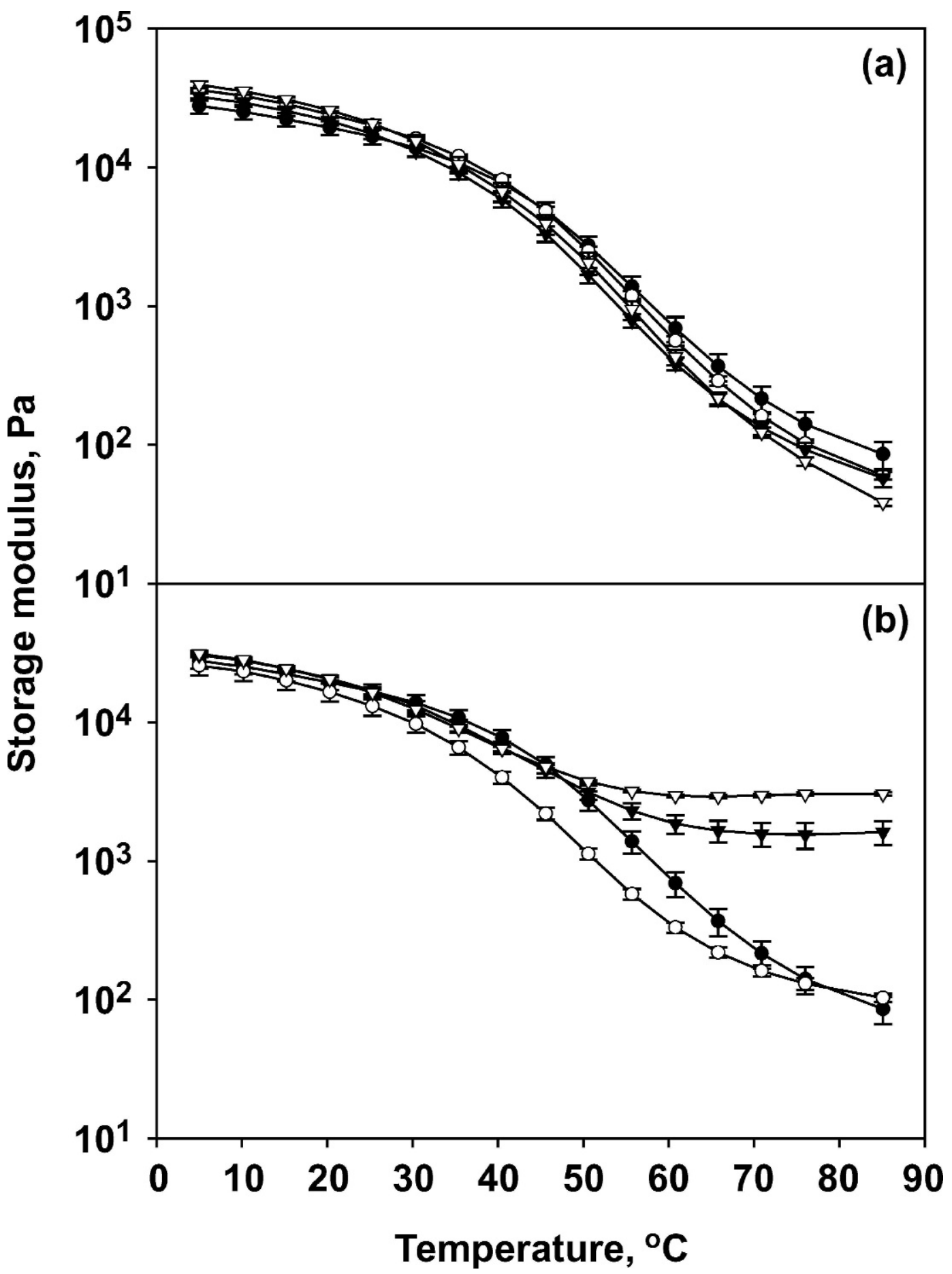

Figure 1. Storage modulus $\left(\mathrm{G}^{\prime}\right)$ as a function of temperature for nonfat pasta filata cheese made with various concentrations of added trisodium citrate (a) and tetrasodium pyrophosphate $(\mathrm{b}): 0 \%(\bullet), 1 \%(\bigcirc), 3 \%(\nabla)$, and $5 \%(\nabla)$ addition of emulsifying salts. Cheese was heated from 5 to $85^{\circ} \mathrm{C}$ at $1^{\circ} \mathrm{C} / \mathrm{min}$. Results are the mean of triplicates with error bars for standard deviations.

with many fibers orientated in a single direction due to the stretching of the curd in that direction during the manufacturing process (Figure 6a). In cheese made with $1 \%$ TSC, a fibrous structure was still observed; however, the fibers appeared to be partially fused together and became thicker (Figure 6b). When high concentrations of TSC (5\%) were used, this fiber fusion greatly increased (Figure 6c). The microstructure for 


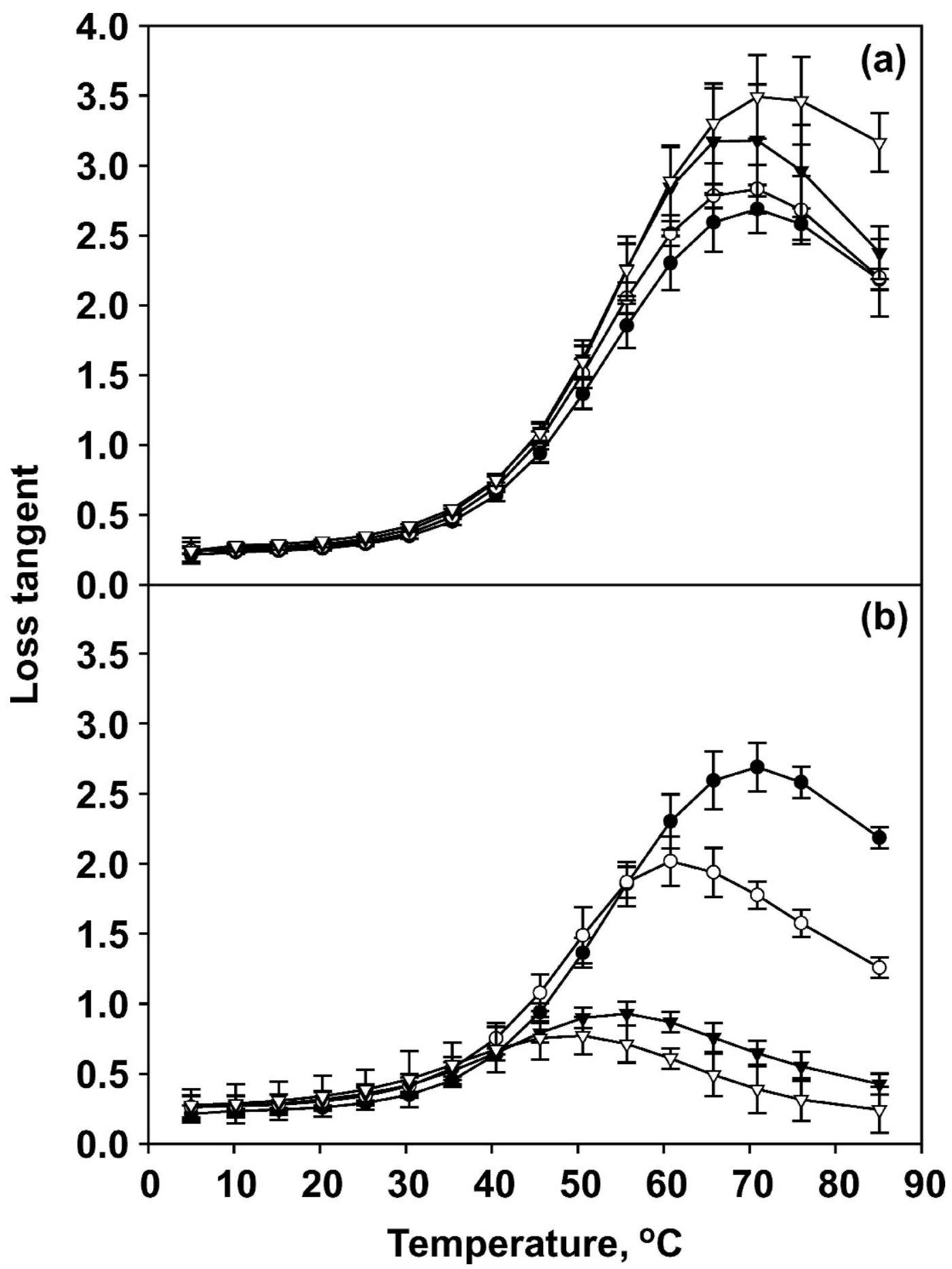

Figure 2. Loss tangent as a function of temperature for nonfat pasta filata cheese made with various concentrations of added trisodium citrate (a) and tetrasodium pyrophosphate (b): $0 \%(\bullet), 1 \%(\bigcirc), 3 \%(\nabla)$, and $5 \%(\nabla)$ addition of emulsifying salts. Cheese was heated from 5 to $85^{\circ} \mathrm{C}$ at $1^{\circ} \mathrm{C} / \mathrm{min}$. Results are the mean of triplicates with error bars for standard deviations.

cheese made with $1 \%$ TSPP (Figure $6 \mathrm{~d}$ ) appeared to be similar to that for cheese made with $1 \%$ TSC (Figure $6 \mathrm{~b})$. In cheese made with $5 \%$ TSPP, the fibrous structure had disappeared (Figure 6e).

\section{DISCUSSION}

Emulsifying salts are commonly used as emulsifying agents for processed cheese manufacture. The addition 


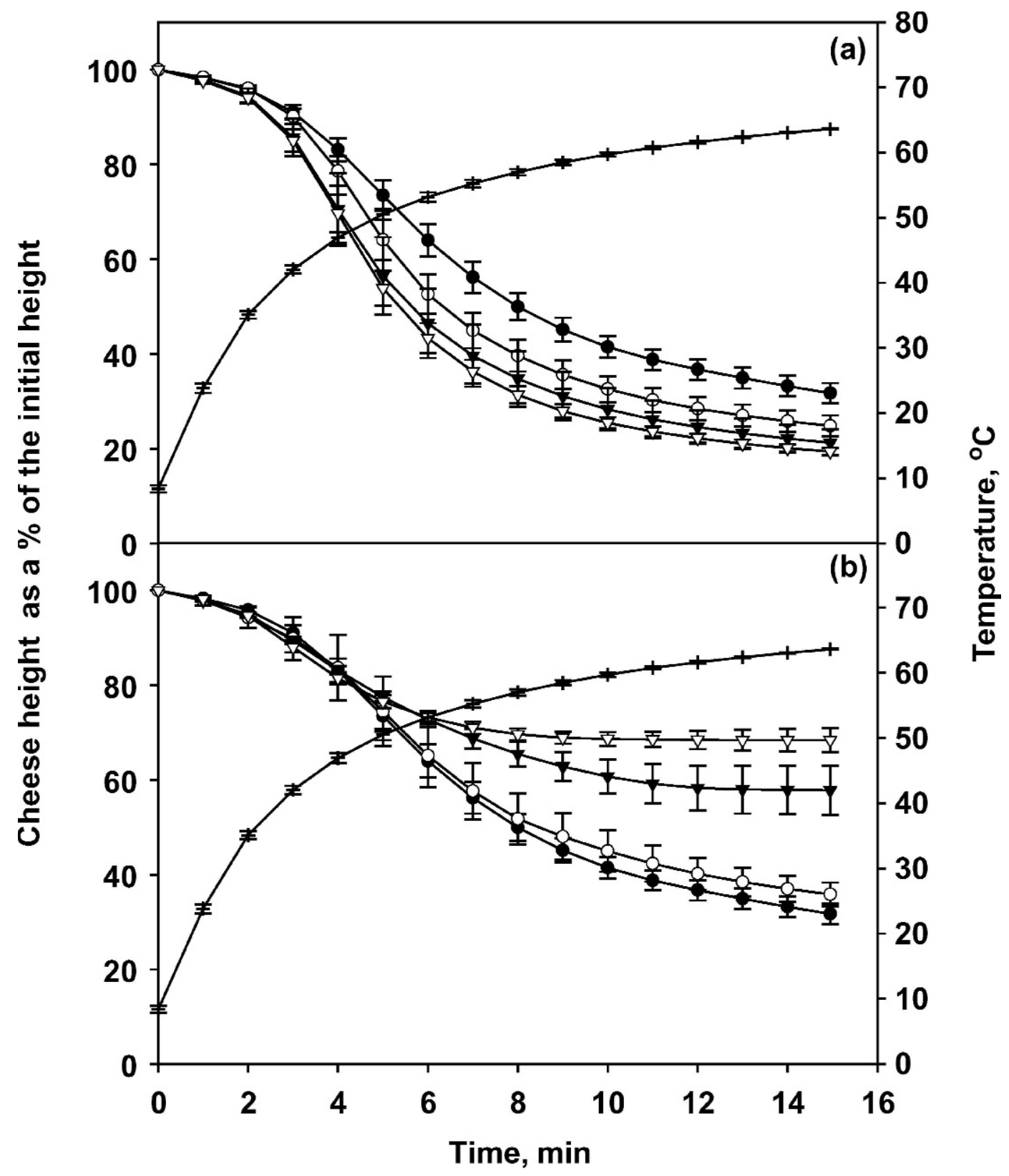

Figure 3. Melt profiles for nonfat pasta filata cheese made with various concentrations of trisodium citrate (a) and tetrasodium pyrophosphate (b): $0 \%(\bullet), 1 \%(\bigcirc), 3 \%(\nabla)$, and $5 \%(\nabla)$ addition of emulsifying salts; cheese temperature during melt profiles $(+)$. Cheese was heated in an oven at $72^{\circ} \mathrm{C}$ and the height recorded by the UW melt profiler. Results are the mean of triplicates with error bars for standard deviations.

of ES increases solubilization of casein (Berger et al., 1998). It is also known that different types of ES influence casein micelles by different mechanisms (Mizuno and Lucey, 2005). In the current study, TSC and TSPP were selected to investigate the impact of ES on the functionality of nonfat pasta filata cheese because they showed contrasting effects on casein micelles in our previous work (Mizuno and Lucey, 2005). In that study, addition of TSC decreased both casein-bound $\mathrm{Ca}$ and
$\mathrm{P}_{\mathrm{i}}$, whereas addition of TSPP increased both caseinbound $\mathrm{Ca}$ and $\mathrm{P}_{\mathrm{i}}$.

Keller et al. (1973) observed changes in composition and rheological properties of Mozzarella cheese by direct acidification with various acids (phosphoric, hydrochloric, acetic, malic, and citric acids). Using different acids for acidification affected the functionality of Mozzarella cheese. However, it also caused an alteration in the moisture content of cheese. Cheng et al. (1997) 


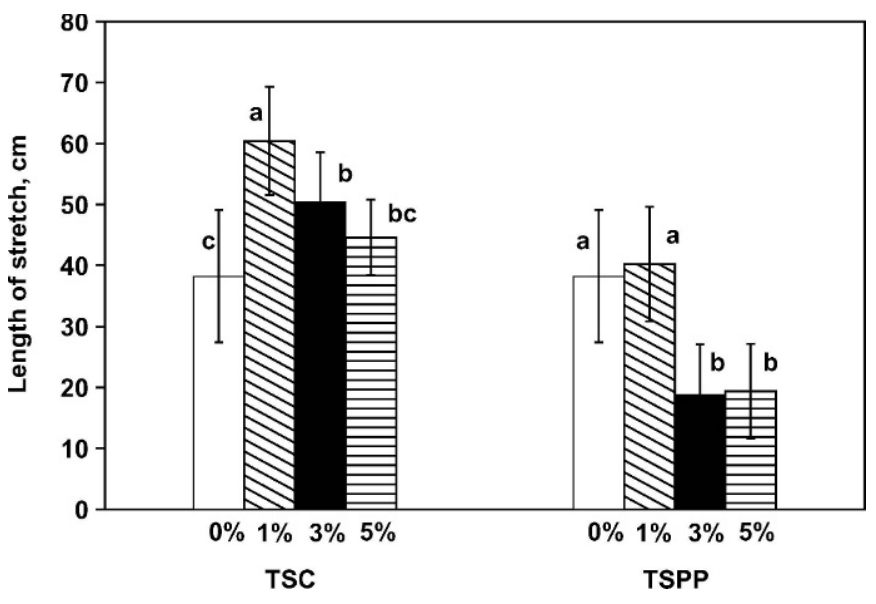

Figure 4. Influence of various concentrations of trisodium citrate (TSC) and tetrasodium pyrophosphate (TSPP) on stretchability of nonfat pasta filata cheese by the fork test at $0,1,3$, and $5 \%$ emulsifying salts addition. Results are the mean of triplicates with error bars for standard deviations. ${ }^{\mathrm{a}, \mathrm{b}, \mathrm{c}}$ Different letters indicate significant differences $(P<0.05)$.

added citrate or phosphate to cheese milk before making cheese to examine effects of added salts on the composition and textural properties of low moisture, partskim Mozzarella cheese. Cheng et al. (1997) also observed an alteration in moisture content in cheese, depending on the type of added salts. A likely reason for the changes in moisture content was the increase in the rennet coagulation time with the addition of these salts due to chelation of $\mathrm{Ca}$ ions and the dispersion of casein micelles (Mohammad and Fox, 1983). In our research, ES was added at the salting step (i.e., during dry-salting) to have a uniform cheese composition among trials. By using this approach, the effects of ES on the functionality of nonfat pasta filata could be investigated without any large changes in cheese composition.

When high concentrations of TSC or TSPP were added to cheese curd, cheese juice could not be extracted (Tables 1 and 2). This might be due to higher concentrations of solubilized casein, which might have contributed to a decrease in the amount of extractable serum. The increase in protein content in cheese juice with the addition of ES also indicates the solubilization of protein by ES. These effects of ES were consistent with the hydration of rennet casein by ES (Ennis et al., 1998). Paulson et al. (1988) also observed that the protein matrix in nonfat Mozzarella was hydrated by salting (i.e., the addition of $\mathrm{NaCl}$ ). Creamer (1985) suggested that an increase in water-holding capacity of proteins by addition of $\mathrm{NaCl}$ was the result of a displacement of Ca from the protein matrix. Although ES work by solubilizing and hydrating casein, ES are better able to hydrate casein due to the higher ability of ES to chelate $\mathrm{Ca}$ compared with $\mathrm{NaCl}$. Increasing the $\mathrm{NaCl}$ content of cheese decreases the amount of expressible serum (Guo et al., 1997; Paulson et al., 1998); increasing the concentration of ES also decreased expressible juice. Paulson et al. (1998) reported that nonfat Mozzarella cheeses that had $\mathrm{NaCl}$ and salt-in-moisture levels of 0.4 to $2.2 \%$ and 0.63 to $3.5 \%$, respectively, had similar melt behavior. All nonfat cheeses in this study had saltin-moisture contents $(\sim 1 \%)$ within the range studied by Paulson et al. (1998), which suggests that the functionality differences observed were due to the addition of ES.

When $1 \%$ TSC was added to cheese curd, insoluble $\mathrm{Ca}$ and $\mathrm{P}$ contents significantly decreased (Table 1). These results suggested that TSC chelated caseinbound $\mathrm{Ca}$ and disrupted some of CCP remaining in cheese. As a result, $\mathrm{Ca}$ and $\mathrm{P}$ from CCP migrated from protein matrix to the cheese serum as soluble $\mathrm{Ca}$ and $P$. At the same time, some casein, which was depleted of $\mathrm{Ca}$, was solubilized and became part of the serum phase. These reactions appeared to be somewhat similar to those observed in dilute milk protein solutions (Mizuno and Lucey, 2005). However, the extent of the decrease in insoluble $\mathrm{Ca}$ and $\mathrm{P}$ with the addition of up to $3 \%$ TSC was smaller than expected. Hassan et al. (2004) reported (in Cheddar cheese) that the proportions of insoluble $\mathrm{Ca}$ as a function of total $\mathrm{Ca}$ content decreased from $\sim 73$ to $\sim 58 \%$ between $1 \mathrm{~d}$ and 4 mo. In our study, $\mathrm{Ca}$, which was dissociated from casein by TSC, might precipitate, for example, as calcium citrate tetrahydrate, $\mathrm{Ca}\left(\mathrm{C}_{6} \mathrm{H}_{5} \mathrm{O}_{7}\right)_{2}$, because cheese is a more concentrated environment than milk, or because of the high $\mathrm{pH}(\sim 6)$ of cheeses made with added TSC. This $\mathrm{pH}$ is higher than that of normal cheese, so Ca phosphate should precipitate more easily in this $\mathrm{pH}$ region. Pastorino et al. (2003) injected a citrate buffer into Cheddar cheese and expected that citrate would react with protein-bound $\mathrm{Ca}$. However, the insoluble $\mathrm{Ca}$ content remained unchanged upon citrate injection. They suggested that it was possible that the added citrate interacted with $\mathrm{Ca}$ and formed insoluble complexes.

When 1\% TSPP was added to cheese, the insoluble $\mathrm{Ca}$ and $\mathrm{P}$ content increased. This was possibly due to the added TSPP combining with protein together with $\mathrm{Ca}$, resulting in the formation of a new type of caseinateCa phosphate complex. A similar reaction was observed when TSPP was added to dilute protein solutions (e.g., skim milk or reconstituted protein solution) (Morr, 1967; Vujicic et al., 1968; Mizuno and Lucey, 2005). The formation of new caseinate-Ca phosphate complexes may help to cross-link caseins, in a similar fashion to the original CCP in milk, resulting in the formation of a cheese protein matrix. These new casein-casein 

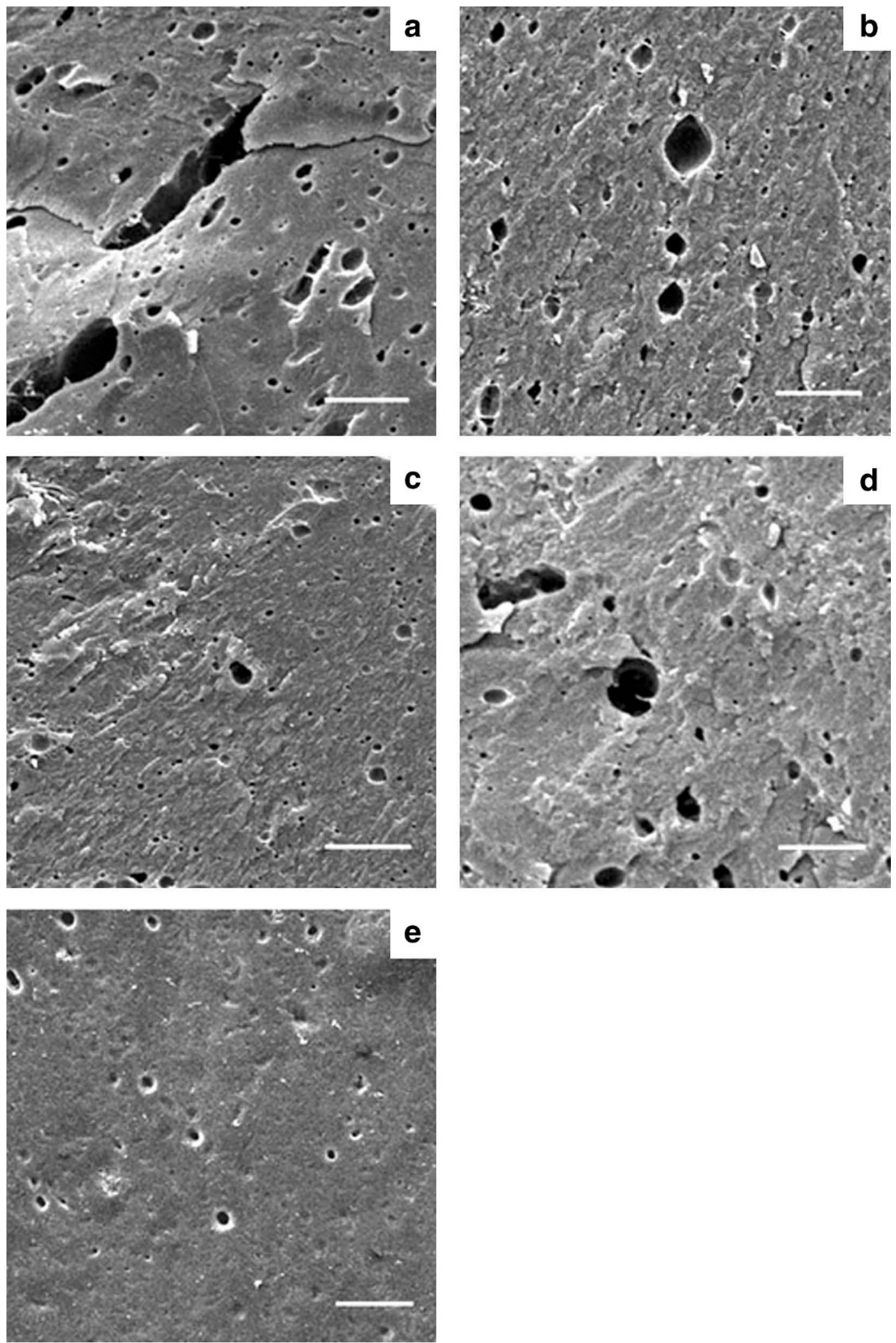

Figure 5. Scanning electron micrographs of nonfat pasta filata cheese made with various concentrations of trisodium citrate (TSC) and tetrasodium pyrophosphate (TSPP): control (a), 1\% TSC (b), 5\% TSC (c), 1\% TSPP (d), and 5\% TSPP (e). Scale bar $=20 \mu \mathrm{m}$. 

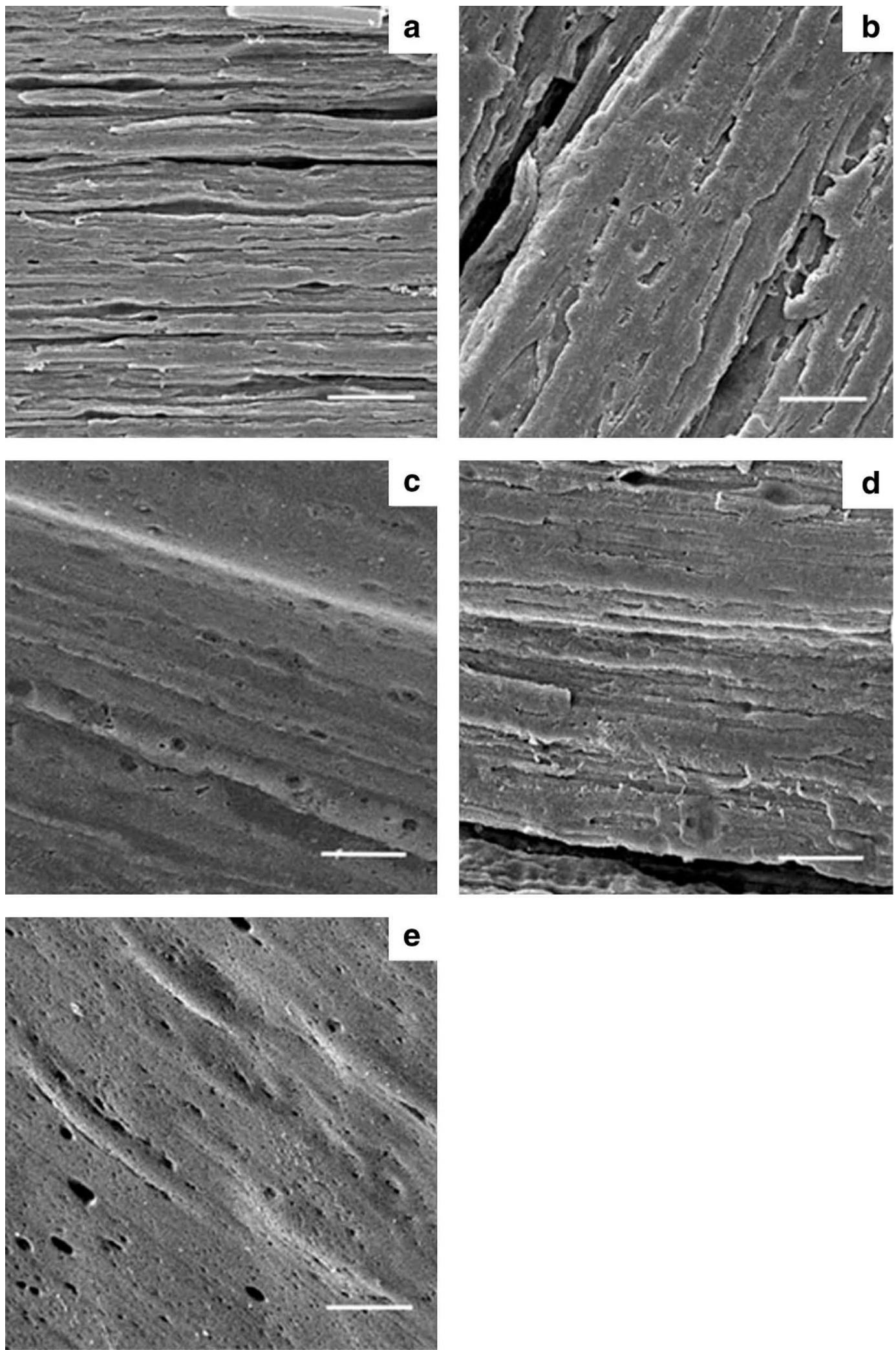

Figure 6. Scanning electron micrographs of nonfat string-type cheese made with various concentrations of trisodium citrate (TSC) and tetrasodium pyrophosphate (TSPP): control (a), 1\% TSC (b), 5\% TSC (c), 1\% TSPP (d), and 5\% TSPP (e). Scale bar $=20 \mu \mathrm{m}$. 
interactions were probably responsible for the alteration in the functionality of cheese.

When control cheese was heated, $G^{\prime}$ values decreased with increasing temperature (Figure 1). This was probably due to the reduction in the size of the contact area between casein particles during heating by individual casein molecules becoming more compact, which is caused by increasing hydrophobic interactions (Lucey et al., 2003). Values of $\mathrm{G}^{\prime}$ at low temperatures had a trend of slightly increasing with increasing concentrations of TSC (Figure 1a), probably due to an increase in the size of the contact area by protein swelling. However, $\mathrm{G}^{\prime}$ values at high temperature decreased with increasing concentrations of added TSC (Figure 1a), probably due to the decrease in the number of CCP cross-links. Thus, these results suggest that CCP crosslinks were more important, and were the more dominant interaction at high temperature compared with low temperature. On the other hand, at low temperature, $G^{\prime}$ values for cheeses with added TSPP were approximately similar to that of control cheese (Figure 1b). However, at high temperature, $G^{\prime}$ values for cheese made with 3 and 5\% TSPP were higher than that for control cheese, and hardly changed with further increasing temperature (Figure 1b). These observations suggested that at low temperatures, TSPP-induced cross-links were not the dominant interaction determining the $G^{\prime}$ value (other interactions were more important). Once cheese was heated, however, these cross-links did not appear to weaken, which may have prevented casein particles from shrinking or increasing in mobility. Texture profile analysis-hardness decreased with increasing concentrations of both ES (Tables 3 and 4). This decrease was possibly due to some disruption of original casein-casein interactions by TSC and TSPP, which were not detected by small strain measurements; for example, the formation of weak spots in protein matrix.

Meltability and stretchability are important functional properties of pasta filata cheese because this cheese is widely used as an ingredient for pizza. The melting and stretching properties of cheese are based on the interactions between casein molecules (Lucey et al., 2003). Meltability increases when the number of casein-casein interactions decreases (e.g., as a result of extensive proteolysis). When TSC was added to cheese curd, increasing meltability was observed in both the UW melt profiler and small-amplitude oscillatory shear tests. These results suggested that TSC dissolved some $\mathrm{CCP}$ due to chelation of $\mathrm{Ca}$, which resulted in a decrease in casein-casein interactions and increased meltability. This was probably due to a decrease in attractive interactions by the reduction in the number of CCP crosslinks and an increase in electrostatic repulsion by expo- sure of the negative charges of phosphoserine residues (Lucey et al., 2003). On the other hand, when TSPP was added to cheese, a remarkable decrease in meltability was observed in both UW Melt Profiler and smallamplitude oscillatory shear tests. Cheng et al. (1997) reported that the addition of a high level $(0.2 \mathrm{~mol} / \mathrm{kg}$ of milk SNF) of phosphate or Ca to cheese milk decreased stretchability and meltability. Further studies are required to understand the reduction in meltability in cheese made with TSPP. It is possible that the formation of a new caseinate-Ca phosphate complex might crosslink caseins, resulting in the formation of more casein-casein interactions, which would reduce meltability. These new interactions between TSPP and casein are also observed in skim milk where they can induce gelation (Vujicic et al., 1968) and these 2 phenomena (gelation and reduced cheese meltability) may be related.

Stretch is the ability of the casein network to maintain its integrity (not break) when continuous stress is applied to the cheese. For a cheese to stretch, casein molecules must interact with each other, release stress (due to stress applied to the cheese), and become pliable (but still maintain sufficient contact between them or the fibers break) (Lucey et al., 2003). It is known that for good stretching properties, relatively high concentrations of intact casein and critical concentrations of $\mathrm{Ca}$ and $\mathrm{P}$ are required (Lucey and Fox, 1993). In our research, cheese made with $1 \%$ TSC had better stretchability than control cheese (i.e., without ES). This was probably because the excessively strong casein-casein interactions in the control cheese were partially destroyed by TSC and the casein matrix was partially weakened. However, further loosening of these casein interactions resulted in a reduction in stretchability because some critical levels of casein-casein interactions presumably give optimum stretchability (under our stretching conditions). In cheese made with the addition of 3\% TSPP, stretchability of cheese markedly decreased. This decrease was probably due to the formation of pyrophosphate-mediated casein-casein interactions (i.e., the same reason as for the decrease in meltability by TSPP). These different types of interactions may not be able to quickly release the stress caused by stretching that is necessary for good stretch.

Scanning electron microscopy showed that there were structural changes in cheese with increasing concentrations of ES. With increasing concentrations of ES, the size and number of serum pockets decreased, and the protein matrix became more homogeneous. Paulson et al. (1998) reported that unsalted $(\mathrm{NaCl})$ nonfat Mozzarella had more serum pockets and a less homogeneous matrix compared with salted cheese. The microstructure of string cheese made with ES revealed the disap- 
pearance of the fibrous structure, due to the fusion of protein caused by the solubilization and hydration of protein with increasing ES addition. It is noteworthy that cheese made with $1 \%$ TSC had a partially fused fibrous structure and greater stretchability than control cheese, which had a clearly fibrous structure.

No major structural differences were observed with scanning electron microscopy between cheese made with TSC and TSPP, although they had significant differences in their functional properties. Taneya et al. (1980) observed that a hard-type processed cheese with $2.2 \%$ polyphosphate did not essentially change its firmness during heating, whereas a soft-type processed cheese with a mixture of $1.0 \%$ citrate and $1.5 \%$ polyphosphate melted during heating. They reported that the microstructure observed by transmission electron microscopy of the hard-type processed cheese had a network-like structure, which was not observed in the soft-type processed cheese. This network-like structure might have been a phosphate-mediated new casein-casein gel network.

In general, it is known that processed cheese that is made with polyphosphate has poorer melting properties than one made with citrate (Gupta et al., 1984; Anonymous, 2004), which is consistent with our results. However, the manufacturing conditions are quite different between processed cheese and the nonfat pasta filata cheese made with ES, which was investigated in our research. In batch-type processed cheese manufacture, the commonly used temperature and time ranges are 70 to $95^{\circ} \mathrm{C}$ and 4 to $15 \mathrm{~min}$, respectively, although they depend on the formulation of the desired product (Fox et al., 2000). Moreover, agitation speeds of 50 to 3000 rpm are common in processed cheese making (Fox et al., 2000). In our research, TSC and TSPP were added at the salting step during cheese manufacture. Even though the curd was stretched in hot water, curd temperature did not exceed $58^{\circ} \mathrm{C}$. Thus, higher temperatures, longer times, and more shear are used in the manufacture of processed cheese than in the cheesemaking procedure used in our research. Therefore, cheese with ES in our research had different textural and functional properties from processed cheese; that is, they still had natural cheese-like properties (e.g., stretch) compared with typical processed cheese.

The addition of TSC and TSPP affected the textural and functional properties of nonfat pasta filata cheese. Hardness and chewiness were improved with both TSC and TSPP addition. The baking properties, such as meltabilty and stretchability, were influenced by the addition of TSC and TSPP in a different manner, suggesting that nonfat pasta filata cheese with the desired textural and functional properties could be produced by choosing the adequate amount and types of ES.

\section{CONCLUSIONS}

This study indicated that ES affected the functional properties of nonfat pasta filata cheese. With increasing concentrations of TSC, insoluble $\mathrm{Ca}$ and $\mathrm{P}$ slightly decreased, suggesting that the TSC chelates some of the insoluble $\mathrm{Ca}$ that remains in cheese, resulting in the solubilization and hydration of caseins. Hardness of cheese with added TSC decreased and meltability increased with increasing concentrations of TSC, due to a decrease in the number of CCP cross-links and an increase in electrostatic repulsion. Addition of $1 \%$ TSC increased stretchability of cheese by partially loosening the protein matrix. Addition of TSPP increased the insoluble $\mathrm{Ca}$ and $\mathrm{P}$ contents. Hardness of cheese at refrigeration temperature decreased with addition of TSPP; however, the $G^{\prime}$ value at high temperature of cheese made with TSPP was higher than that for control and meltability and stretchability remarkably decreased. This could be due to the formation of new casein-casein interactions, involving pyrophosphate and $\mathrm{Ca}$, which have a major impact on cheese texture at high temperatures and are less critical at low temperatures where other interactions may be more dominant.

\section{ACKNOWLEDGMENTS}

The authors gratefully acknowledge the technical assistance of Philip Oshel in the use of the scanning electron microscope. The authors appreciate the financial support by Morinaga Milk Industry Co., Ltd. The donation of phosphate salts by Astaris LLC is also appreciated. The authors are grateful for the financial support of this program by the Wisconsin Center for Dairy Research and Dairy Management, Inc. (Rosemont, IL).

\section{REFERENCES}

Anonymous. 2004. Innovations in dairy. Controlling processed cheese functionality. Technical Bulletins, DMI, Inc. Online. Available http://www.extraordinarydairy.com/archive/ innov_001_may_04.pdf. Accessed Mar. 23, 2005.

Barz, R. L., and C. P. Cremer, inventors. 1993. Process of making acceptable Mozzarella cheese without aging. Leprino Foods Company, assignee. US Pat. No. 5,200,216.

Barz, R. L., and C. P. Cremer, inventors. 1996. Process of making Mozzarella cheese. Leprino Foods Company, assignee. US Pat. No. 5,567,464.

Barz, R. L., C. P. Cremer, and A. V. Durkin, inventors. 1999. Process of making a soft or semi-soft fibrous cheese. Leprino Foods Company, assignee. US Pat. No. 5,902,625.

Berger, W., H. Klostermeyer, K. Merkenich, and G. Uhlman. 1998. Processed Cheese Manufacture, A JOHA Guide. BK Giulini Chemie GmbH \& Co., OHG, Ladenburg, Germany.

Bourne, M. C. 1968. Texture profile of ripening pears. J. Food Sci. $33: 223-226$

Cheng, L., M. A. Augustin, I. R. McKinnon, and B. J. Sutherland. 1997. The effect of mineral salt addition on Mozzarella cheesemaking. Aust. J. Dairy Technol. 52:8-14.

Creamer, L. K. 1985. Water absorption by renneted casein micelles. Milchwissenschaft 40:589-591. 
Dahlstrom, D. G., J. Wiegand, and W. R. Aimutis. 2001. Pasta filata cheese. Land O'Lakes, assignee. US Pat. No. 6,319,526.

Ennis, M. P., M. M. O’Sullivan, and D. M. Mulvihill. 1998. The hydration behaviour of rennet caseins in calcium chelating salt solution as determined using a rheological approach. Food Hydrocoll. 12:451-457.

Guo, M. R., J. A. Gilmore, and P. S. Kindstedt. 1997. Effect of sodium chloride on the serum phase of Mozzarella cheese. J. Dairy Sci. 80:3092-3098.

Gupta, S. K., C. Karahadian, and R. C. Lindsay. 1984. Effect of emulsifier salts on textural and flavor properties of processed cheeses. J. Dairy Sci. 67:764-778.

Gunasekaran, S., and M. M. Ak. 2002. Cheese Rheology and Texture. CRC Press LLC, Boca Raton, FL.

Fox, P. F., T. P. Guinee, T. M. Cogan, and P. L. H. McSweeney. 2000. Fundamentals of Cheese Science. Aspen Publishers, Inc., Gaithersburg, MD.

Hassan, A., M. E. Johnson, and J. A. Lucey. 2004. Changes in the proportions of soluble and insoluble calcium during the ripening of Cheddar cheese. J. Dairy Sci. 87:854-862.

IDF. 1982a. Cheese and processed cheese: Determination of total solids content of cheese and processed cheese. 4A:1982. International Dairy Federation, Brussels, Belgium.

IDF. 1982b. Milk, cream and evaporated milk: Determination of total solids content of cheese and processed cheese. 21A:1982. International Dairy Federation, Brussels, Belgium.

IDF. 1986. Determination of nitrogen content (Kjeldahl method) and calculation of crude protein content. 20A:1986. International Dairy Federation, Brussels, Belgium.

IDFA. 2004. Dairy Facts 2004 Edition. International Dairy Food Association, Washington, DC.

Keller, B., N. F. Olson, and T. Richardson. 1973. Mineral retention and rheological properties of Mozzarella cheese made by direct acidification. J. Dairy Sci. 57:174-180.

Kuo, M. I., and S. Gunasekaran. 2003. Effect of frozen storage on physical properties of pasta filata and nonpasta filata Mozzarella cheeses. J. Dairy Sci. 86:1108-1117.

Lucey, J. A. 2002. Formation and physical properties of milk protein gels. J. Dairy Sci. 85:281-294.

Lucey, J. A., and P. F. Fox. 1993. Importance of calcium and phosphate in cheese manufacture: A review. J. Dairy Sci. 76:1714-1724.

Lucey, J. A., M. E. Johnson, and D. S. Horne. 2003. Perspectives on the basis of rheology and texture properties of cheese. J. Dairy Sci. 86:2725-2743.

Marshall, R. T. 1992. Standard Methods for the Examination of Dairy Products. 16th ed. American Public Health Association, Washington, DC.

Merrill, R. K., C. J. Oberg, and D. J. McMahon. 1994. A method for manufacturing reduced fat Mozzarella cheese. J. Dairy Sci. 77:1783-1789.

Metzger, L. E., D. M. Barbano, and P. S. Kindstedt. 2001a. Effect of milk preacidification on low fat Mozzarella cheese. III. Post-melt chewiness and whiteness. J. Dairy Sci. 84:1357-1366.

Metzger, L. E., D. M. Barbano, P. S. Kindstedt, and M. R. Guo. 2001b. Effect of milk preacidification on low fat Mozzarella cheese. II. Chemical and functional properties during storage. J. Dairy Sci. 84:1348-1356.
Metzger, L. E., D. M. Barbano, M. A. Rudan, and P. S. Kindstedt. 2000. Effect of milk preacidification on low fat Mozzarella cheese. I. Composition and yield. J. Dairy Sci. 83:648-658.

Mizuno, R., and J. A. Lucey. 2005. Effects of emulsifying salts on the turbidity and calcium-phosphate-protein interactions in casein micelles. J. Dairy Sci. 88:3070-3078.

Mohammad, K. S., and P. F. Fox. 1983. Influence of some polyvalent organic acids and salts on colloidal stability of milk. J. Soc. Dairy Technol. 36:112-117.

Morr, C. V. 1967. Some effects of pyrophosphate and citrate ions upon the colloidal caseinate-phosphate micelles and ultrafiltrate of raw and heated skimmilk. J. Dairy Sci. 50:1038-1044.

Morris, H. A., C. Holt, B. E. Brooker, J. M. Banks, and W. Manson. 1988. Inorganic constituents of cheese: Analysis of juice from a one-month-old Cheddar cheese and the use of light and electron microscopy to characterize the crystalline phases. J. Dairy Res. 55:255-268.

Muthukumarappan, K., Y. C. Wang, and S. Gunasekaran. 1999. Estimating softening point of cheeses. J. Dairy Sci. 82:2280-2286.

Park, Y. W. 2000. Comparison of mineral and cholesterol composition of different commercial goat milk products manufactured in USA. Small Rumin. Res. 37:115-124.

Pastorino, J., C. L. Hansen, and D. J. McMahon. 2003. Effect of sodium citrate on structure-function relationships of Cheddar cheese. J. Dairy Sci. 86:3113-3121.

Paulson, B. M., D. J. McMahon, and C. J. Oberg. 1998. Influence of sodium chloride on appearance, functionality, and protein arrangements in nonfat Mozzarella cheese. J. Dairy Sci. 81:2053-2064.

Rizvi, S. S. H., A. Shukla, and J. Srikiatden, inventors. 1999. Processed Mozzarella cheese. Cornell Research Foundation, Inc., assignee. US Pat. No. 5,925,398.

Rudan, M. A., and D. M. Barbano. 1998. A model of Mozzarella cheese melting and browning during pizza baking. J. Dairy Sci. 81:2312-2319.

Rudan, M. A., D. M. Barbano, M. R. Guo, and P. S. Kindstedt. 1998. Effect of the modification of fat particle size by homogenization on composition, proteolysis, functionality, and appearance of reduced fat Mozzarella cheese. J. Dairy Sci. 81:2065-2076.

Rudan, M. A., D. M. Barbano, J. J. Yun, and P. S. Kindstedt. 1999. Effect of fat reduction on chemical composition, proteolysis, functionality, and yield of Mozzarella cheese. J. Dairy Sci. 82:661-672.

SAS Institute. 1999. SAS System for Windows Release 6.12. SAS Institute, Inc., Cary, NC.

Sheehan, J. J., and T. P. Guinee. 2004. Effect of $\mathrm{pH}$ and calcium level on the biochemical, textural and functional properties of reducedfat Mozzarella cheese. Int. Dairy J. 14:161-172.

Taneya, S., T. Kimura, T. Izutsu, and W. Buchheim. 1980. The submicroscopic structure of processed cheese with different melting properties. Milchwissenschaft 35:479-481.

Tunick, M. H., K. L. Mackey, P. W. Smith, and V. H. Holsinger. 1991. Effects of composition and storage on the texture of Mozzarella cheese. Neth. Milk Dairy J. 45:117-125.

Vujicic, I., J. M. deMan, and I. L. Woodrow. 1968. Interaction of polyphosphate and citrate with skimmilk proteins. Can. Inst. Food Sci. Technol. J. 1:17-21. 